\title{
DNA fragmentation is an early event in cytokine-induced islet beta-cell destruction
}

\author{
A. Rabinovitch ${ }^{1}$, W. L.Suarez-Pinzon ${ }^{1}$, Y.Shi ${ }^{2}$, A. R. Morgan ${ }^{3}$, R. C. Bleackley \\ ${ }^{1}$ Department of Medicine and the Muttart Diabetes Research and Training Centre, University of Alberta, Edmonton, Alberta, \\ Canada \\ ${ }^{2}$ Department of Immunology, University of Alberta, Edmonton, Alberta, Canada \\ ${ }^{3}$ Department of Biochemistry, Centre, University of Alberta, Edmonton, Alberta, Canada
}

Summary The cytokines, interleukin 1 , tumour necrosis factor, and interferon gamma are cytotoxic to islet beta cells, however, their mechanisms of beta-cell killing are not fully characterized. Since DNA damage is a mechanism of cytokine-induced cell death in some cell types, we sought evidence for cytotoxic effects of cytokines at a nuclear level in islet beta cells by measuring DNA fragmentation in rat islets and islet beta-cell lines. The individual cytokines, interleukin 1 $(10 \mathrm{U} / \mathrm{ml})$, tumour recrosis factor $\left(10^{3} \mathrm{U} / \mathrm{ml}\right)$ and interferon gamma $\left(10^{3} \mathrm{U} / \mathrm{ml}\right)$ inhibited insulin release from rat islets, but did not cause DNA fragmentation or destroy islet cells; by contrast, combination of the three cytokines induced DNA fragmentation and islet-cell death. Cytokine-induced DNA fragmentation preceded cell lysis in islet beta-cell lines (RINm5F, rat insulinoma cells; and NIT-1, NOD/Lt mouse transgenic beta cells), whereas in non-islet cell lines (GH-3, rat pituitary; and PC-12, rat adrenal) the cytokines induced cell lysis and no or late DNA fragmentation. Nicotinamide prevented both DNA fragmentation and destruction of RINm5F islet cells by the cytokines. These findings identify DNA as an early target of cytokine action in islet beta cells, and implicate DNA fragmentation as a mechanism of cytokine-induced beta-cell destruction. [Diabetologia (1994) 37: 733-738]

Key words Islet beta cells, cytokines, interleukin 1, tumour necrosis factor, interferon gamma, DNA damage.
Infiltration of the pancreatic islets by immune/inflammatory cells (insulitis), followed by loss of the insulinproducing beta cells is the characteristic histologic feature of IDDM. It is not known, however, how islet beta-cell destruction may be mediated by the insulitis process. This may involve direct contacts between the infiltrating monocytic/lymphocytic cells (effectors) and islet beta cells (targets) and/or may result from the release of soluble mediators from the effector cells.

Received: 20 October 1993

and in revised form: 17 January 1994

Corresponding author: Dr. A. Rabinovitch, 430 Heritage Medical Research Centre, University of Alberta, Edmonton, Alberta T6G 2S2, Canada

Abbreviations: IDDM, Insulin-dependent diabetes mellitus; IL-1, interleukin-1; TNF, tumour necrosis factor; IFN $\gamma$, interferon gamma; NO, nitric oxide; L-NMMA, L-NG-monomethyl arginine.
Cytokines produced by activated cells infiltrating islets are candidate molecules mediating impaired function and destruction of islet beta cells in IDDM [1-3]. A variety of mechanisms have been proposed to explain the cytotoxic effects of cytokines on islet beta cells [3-6], and these mechanisms include nitric oxide formation [5]. Recently Fehsel et al. [7] reported that nitric oxide-induced islet-cell lysis is preceded by DNA damage. Since DNA damage is a mechanism of cytokine-induced cell death in various cell types [8], we asked if cytokines can induce DNA damage in islet beta cells and whether this mechanism might be involved in cytokine-induced killing of the beta cells.

\section{Materials and methods}

Cytokines and chemicals. Rccombinant human interleukin 1 (IL-1 $\beta, 2-4 \times 10^{7} \mathrm{U} / \mathrm{mg}$ ) was provided by The Upjohn Co. (Kalamazoo, Mich., USA), recombinant murine tumour necrosis 
factor $\left(\mathrm{TNF} \alpha, 1.2 \times 10^{7} \mathrm{U} / \mathrm{mg}\right)$ and recombinant murine interferon gamma (IFN $\gamma, 8 \times 10^{6} \mathrm{U} / \mathrm{mg}$ ) were provided by Genentech (South San Francisco, Calif., USA). The chemicals were purchased from the following sources: medium RPMI 1640, HEPES, and fetal calf serum, Gibco BRL (Burlington, Ontario, Canada): ${ }^{125} \mathrm{IUdR}$ and ${ }^{51} \mathrm{Cr}$ sodium chromate, Dupont (Mississauga, Ontario, Canada); proteinase $\mathrm{K}$ and RNAse $\mathrm{A}$, Boehringer Mannheim (Laval, Quebec, Canada); nicotinamide and other chemicals, Sigma (St.Louis, Mo., USA).

Studies with whole islets. Pancreatic islets were isolated from adult Wistar-Furth rats (Charles River, St. Constant, Quebec, Canada), by collagenase enzyme digestion of the pancreas [9], with ductal injection of the enzyme [10]. The islets were incubated at $37^{\circ} \mathrm{C}$ in $5 \% \mathrm{CO}_{2}$ in free-floating culture in RPMI 1640 medium supplemented with $10 \%$ fetal calf serum, $100 \mathrm{U} / \mathrm{ml}$ penicillin, $100 \mu \mathrm{g} / \mathrm{ml}$ streptomycin, $20 \mu \mathrm{g} / \mathrm{ml}$ amphotericin B, and $10 \mathrm{mmol} / \mathrm{L} \mathrm{HEPES}$ buffer (complete medium) for $48 \mathrm{~h}$ before experimentation.

In the first set of experiments, islets $(1,000$ per $35 \times 10 \mathrm{~mm}$ petri dish) were incubated for $24 \mathrm{~h}$ at $37^{\circ} \mathrm{C}$ in $5 \% \mathrm{CO}_{2}$ in $2.7 \mathrm{ml}$ complete medium without and with IL-1 $\beta(10 \mathrm{U} / \mathrm{ml})$, TNF $\alpha$ $\left(10^{3} \mathrm{U} / \mathrm{ml}\right)$ and IFN $\gamma\left(10^{3} \mathrm{U} / \mathrm{ml}\right)$, added one at a time and in combination. After this period, the insulin concentration of the incubation medium was measured by radioimmunoassay using rat insulin standards and a kit (Pharmacia, Uppsala, Sweden). The islets were collected and washed three times in ice-cold phosphate-buffered saline ( $\mathrm{pH}$ 7.4). DNA fragmentation was assayed by a modification of the method of Duke and Sellins [11]. The islets were suspended in $500 \mu$ l of lysis buffer $(5 \mathrm{mmol} / \mathrm{T}$ Tris$\mathrm{HCl}, 2 \mathrm{mmol} / \mathrm{EDTA}, 0.5 \%$ Triton X-100, $\mathrm{pH} 8.0$ ), vortexed vigorously, sonicated on ice (Sonic 1510, B. Braun Melsungen AG, South San Francisco, Calif., USA) at 100 watts for 30 s, then incubated on ice for $20 \mathrm{~min}$, and centrifuged for $20 \mathrm{~min}$ $(14,000 \times g)$. The supernatant, containing fragmented (soluble) DNA was transferred to a separate tube. Lysis buffer $(500 \mu \mathrm{l})$ was added to the pellet containing insoluble DNA. Both samples were treated with proteinase $\mathrm{K}$ (final concentration $0.4 \mathrm{mg} / \mathrm{ml}$ ) for $1 \mathrm{~h}$ at $50^{\circ} \mathrm{C}$; then the enzyme was inactivated at $65^{\circ} \mathrm{C}$ for $5 \mathrm{~min}$. RNAse A was added (final concentration $0.5 \mathrm{mg} / \mathrm{ml}$ ) for $2 \mathrm{~h}$ at $37^{\circ} \mathrm{C}$; then $\mathrm{NaOH}(0.2 \mathrm{~mol} / \mathrm{l})$ was added for $2 \mathrm{~min}$ at $96^{\circ} \mathrm{C}$. The samples were cooled to $4^{\circ} \mathrm{C}$ for $3 \mathrm{~min}$ and $\mathrm{HCl}(0.1 \mathrm{~mol} / \mathrm{l})$ was added to bring the $\mathrm{pH}$ to 8.0 . To $100 \mu \mathrm{l}$ samples in $12 \times 75 \mathrm{~mm}$ borosilicate glass tubes, $1.2 \mathrm{ml}$ of ethidium bromide solution ( $\mathrm{pH}$ 8.0) was added; the samples were vortexed, and DNA concentrations were measured with a Turner 450 fluorometer (Mountain View, Calif., USA) [12]. Percent DNA fragmentation was calculated as $100 \% \times$ soluble DNA/(soluble + in soluble $=$ total DNA) .

In another set of experiments, islets were incubated with the combination of IL- $1 \beta$, TNF $\alpha$ and IFN $\gamma$ for 12,24 and 48 h. DNA was extracted and DNA fragments were visualized by agarose gel electrophoresis [13]. A positive control for DNA fragmentation was provided by DNA extracted from a mouse T-cell hybridoma, A1.1 incubated with an anti-T-cell receptor monoclonal antibody [14].

Studies with cell lines. RINm5F is an insulinoma cell line derived from the NEDH rat islet cell tumor [15]. NIT-1 is an islet betacell line from a transgenic NOD/Lt mouse [16] and was kindly provided by Dr. M. Appel, (Worcester, Mass., USA). GH-3, a rat pituitary cell-line, and PC- 12 , a rat adrenal pheochromocytoma cell line, were obtained from American Type Culture Collection. RINm5F, NIT-1, and GH-3 cell monolayers were dissociated into single cells by incubation for $5 \mathrm{~min}$ at $37^{\circ} \mathrm{C}$ in $0.05 \%$ trypsin $/ 0.02 \%$ EDTA in $\mathrm{Ca}^{2+} / \mathrm{Mg}^{2+}$-free phosphate-buffered saline and PC-12 cells were dissociated by mechanical disruption. All cells were washed and incubated at $37^{\circ} \mathrm{C}$ in $5 \% \mathrm{CO}_{2}$ in complete medium for $24 \mathrm{~h}$ before experimentation.

In the first set of experiments, the kinetics of cytokine-induced DNA damage and cell lysis were compared in the different cell lines by radiolabelling DNA and cytoplasmic proteins [13]. Cell DNA was labelled by incubating $10^{6}$ cells $/ \mathrm{ml}$ with $1.62 \mu \mathrm{Ci} / \mathrm{ml}$ ${ }^{125} \mathrm{IUdR}$ in complete medium for $16 \mathrm{~h}$. Cytoplasmic proteins were labelled in other cells, in parallel, by incubating $10^{6} \mathrm{cells} / \mathrm{ml}$ with $10 \mu \mathrm{Ci} / \mathrm{ml}^{51} \mathrm{Cr}$ sodium chromate in complete medium for $90 \mathrm{~min}$. The cellswere then washed, seeded $\left(10^{6}\right.$ cells per $35 \times 10 \mathrm{~mm}$ petri dish) and incubated at $37^{\circ} \mathrm{C}$ in $5 \% \mathrm{CO}_{2}$ in $2.7 \mathrm{ml}$ complete medium without and with cytokines for $1-18 \mathrm{~h}$. The ${ }^{125}$ IUdR-labelled cells were collected; DNA was then extracted and separated into a detergent-soluble fraction (fragmentedDNA) and an insoluble fraction, and these were counted $\left.{ }^{125} \mathrm{I}\right)$ in a gamma counter [13]. DNA fragmentation was calculated as $100 \% \times$ soluble ${ }^{125}$ I-DNA/(soluble + insoluble ${ }^{125}$ I-DNA). Medium was collected from the ${ }^{51} \mathrm{Cr}$-labelled cells and ${ }^{51} \mathrm{Cr}$ was counted in a gamma counter. Percent cytokine-induced celllysis $\left({ }^{51} \mathrm{Cr}\right.$ release $)$ was calculated as $100 \% \times(\mathrm{cpm}$ with cytokines - cpm without cytokines)/(total cpm - cpm without cytokines). Total cpm was measured by dissolving the cells in $4 \%$ Triton X-100.

In the last set of experiments, RINm5F cells were incubated at $37^{\circ} \mathrm{C}$ in $5 \% \mathrm{CO}_{2}$ in complete medium without and with cytokines, and without and with nicotinamide $(0.1,1.0$ and $10 \mathrm{mmol} / 1)$ for $18 \mathrm{~h}$. DNA fragmentation and total DNA were assayed as described above for whole islets $[12,13]$.

\section{Statistical analysis}

Data were computed as means \pm SEM and groups of data were compared by Student's unpaired $t$-test.

\section{Results}

Concentrations of IL- $1 \beta(10 \mathrm{U} / \mathrm{ml})$, TNF $\alpha\left(10^{3} \mathrm{U} / \mathrm{ml}\right)$ and IFN $\gamma\left(10^{3} \mathrm{U} / \mathrm{ml}\right)$ with maximal inhibitory effects on insulin release [17] did not affect DNA fragmentation or islet-cell recovery - measured as DNA levels in the islets (Table 1). Combination of the cytokines, however, further inhibited insulin release, significantly increased DNA fragmentation, and decreased DNA levels in the islets. To determine if DNA fragmentation

Table 1. Effects of cytokines on insulin release, DNA fragmentation and DNA levels in rat islets

\begin{tabular}{llll}
\hline $\begin{array}{l}\text { Additions } \\
\text { (U/ml) }\end{array}$ & $\begin{array}{l}\text { Insulin } \\
\text { (nmoles) }\end{array}$ & $\begin{array}{l}\text { DNA (\% frag- } \\
\text { mentation) }\end{array}$ & $\begin{array}{l}\text { DNA } \\
\text { (ng, total) }\end{array}$ \\
\hline None & $1890 \pm 90$ & $8.2 \pm 0.2$ & $4209 \pm 114$ \\
IL-1 $\beta 10$ & $1005 \pm 30^{\mathrm{a}}$ & $8.6 \pm 0.3$ & $4293 \pm 176$ \\
TNF $\alpha 10^{3}$ & $1515 \pm 45^{\mathrm{b}}$ & $8.3 \pm 0.3$ & $4491 \pm 240$ \\
IFN $\gamma 10^{3}$ & $1425 \pm 120^{\mathrm{b}}$ & $8.4 \pm 0.4$ & $4036 \pm 147$ \\
IL-1 $\beta 10+\mathrm{TNF} \alpha$ & & & \\
$10^{3}+\mathrm{IFN} \gamma 10^{3}$ & $855 \pm 45^{\mathrm{a}}$ & $13.6 \pm 0.9^{\mathrm{a}}$ & $3402 \pm 20^{\mathrm{a}}$ \\
\hline
\end{tabular}

Rat islets ( 1000 per dish) were incubated for $24 \mathrm{~h}$ in the absence and presence of cytokines, added one at a time and in combination at the concentrations indicated. Insulin accumulation in medium and DNA levels in islets (total and \% fragmented) were measured after 24-h incubation. Results are means \pm SEM of five to six observations. ${ }^{\mathrm{a}} p<0.01,{ }^{\mathrm{b}} p<0.05$ vs corresponding value for islets incubated in the absence of cytokines 


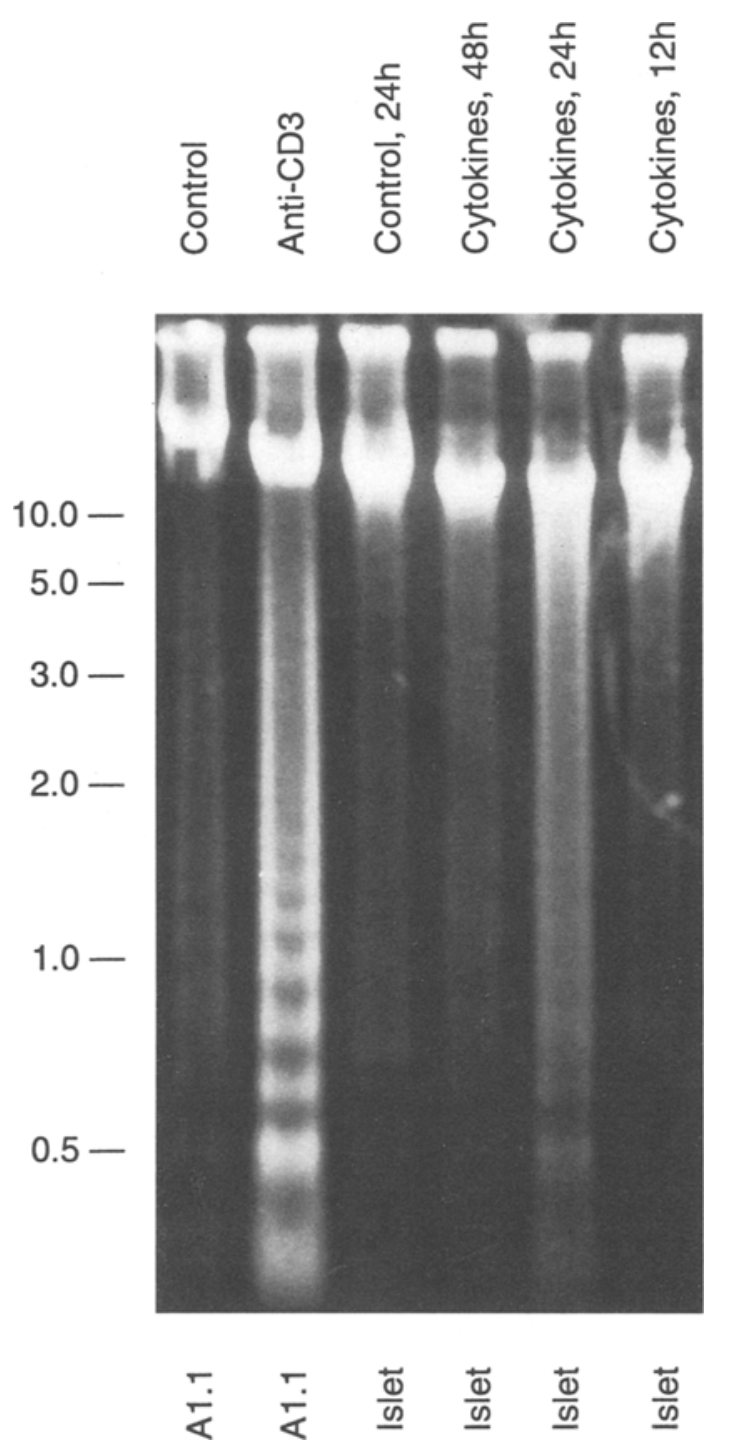

Fig.1. Analysis of DNA fragmentation by agarose gel electrophoresis and ethidium bromide staining. DNA was extracted from a mouse T-cell hybridoma line A1.1 after $12 \mathrm{~h}$ incubation without (control) and with an anti-T-cell receptor monoclonal antibody (anti-CD3). Anti-CD3 induced DNA fragmentation in A1.1 cells, revealed as a ladder pattern of oligonucleosomal fragments whose molecular sizes are multiples of $\approx 200$ base pairs. Molecular sizes in kilobases are indicated to the left of the gel. DNA was also extracted from rat islets incubated with interleukin 1 (IL-1 $\beta, 10 \mathrm{U} / \mathrm{ml}$ ), tumour necrosis factor $(\mathrm{TNF} \alpha$, $10^{3} \mathrm{U} / \mathrm{ml}$ ) and interferon gamma (IFN $\gamma, 10^{3} \mathrm{U} / \mathrm{ml}$ ) in combination (cytokines) for 12,24 and $48 \mathrm{~h}$, and in control medium for $24 \mathrm{~h}$. A ladder pattern of DNA fragments is seen for islets incubated with cytokines for $24 \mathrm{~h}$. Results are shown for a representative of three experiments

measured as soluble DNA (Table 1) represented genuine fragmentation of nuclear DNA into oligonucleosomal fragments, DNA was extracted from the islet cells and examined by gel electrophoresis. As a positive control, mouse T-cell hybridoma A1.1 cells were incubated with an anti-CD3 monoclonal antibody to induce DNA fragmentation, visualized as a ladder pattern of

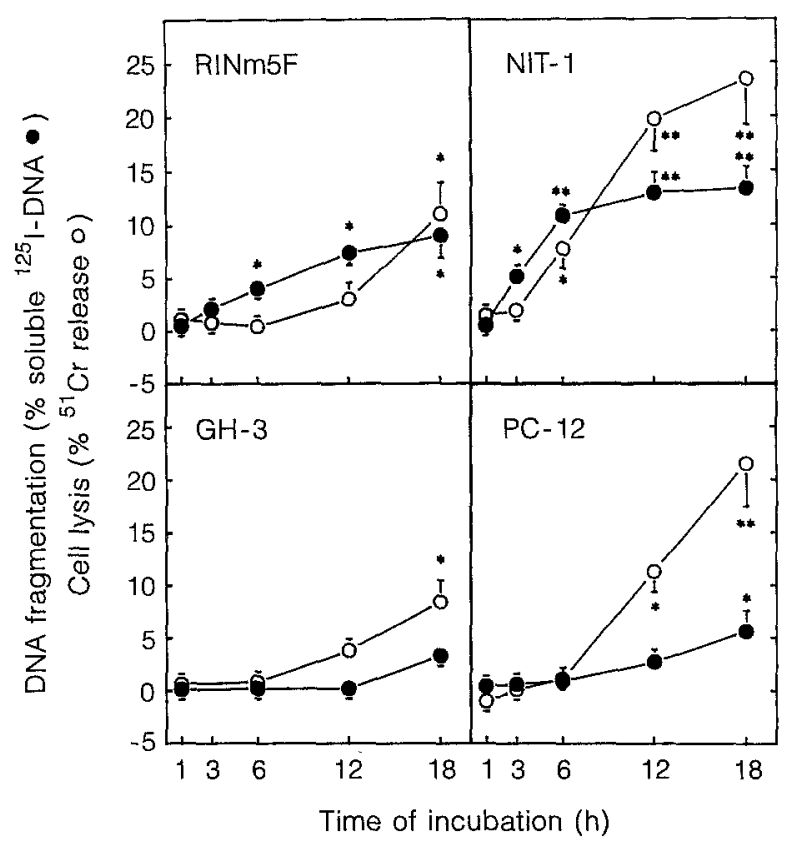

Fig. 2. Time course effects of the cytokine combination of interleukin 1 (IL-1 $\beta, 10 \mathrm{U} / \mathrm{ml}$ ), tumour necrosis factor (TNF $\alpha$, $10^{3} \mathrm{U} / \mathrm{ml}$ ), and interferon gamma (IFN $\gamma, 10^{3} \mathrm{U} / \mathrm{ml}$ ) on DNA fragmentation (\% ${ }^{125} \mathrm{I}-\mathrm{DNA}$ in the soluble fraction of DNA extracted from cells) (O) and cell lysis (\% ${ }^{51} \mathrm{Cr}$-labelled cytosolic proteins released from cells) $(O)$ in a rat insulinoma cell line (RINm5F), a transgenic NOD/Lt mouse islet beta-cell line (NIT1 ), a rat pituitary cell line (GH-3) and a rat adrenal cell line (PC12). Data are mean $\pm S E M$ incremental values above those for cells incubated for the same times in cytokine-free medium (controls) in four experiments. For controls, cell lysis (spontaneous ${ }^{51} \mathrm{Cr}$ release) was $<15 \%$ and DNA fragmentation was $<10 \%$. $* p<0.05, * * p<0.01$ vs cytokine effects at $1-\mathrm{h}$ incubation

oligonucleosomal fragments whose molecular sizes are multiples of approximately 200 base pairs (Fig. 1). The cytokine combination of IL- $1 \beta$, TNF $\alpha$ and IFN $\gamma$ induced fragmentation of islet-cell DNA into a similar ladder pattern at $24 \mathrm{~h}$ of incubation (Fig. 1). These cytokine-induced oligonucleosomal bands were of low intensity, corresponding to the small increase in percentage of total islet-cell DNA that underwent fragmentation after exposure to the cytokine combination $(-5 \%$, Table 1$)$. However, the assay of percent soluble DNA probably gives an underestimation of the percent DNA fragmentation, due to some DNA fragments appearing in the insoluble pellet. This is suggested by the results in Figure 1 showing that a large proportion of DNA from islets incubated with cytokines for $24 \mathrm{~h} \mathrm{had}$ migrated only a small distance down the gel compared to the DNA band from islets incubated in control medium for $24 \mathrm{~h}$. Thus, it appears that most of the DNA remained as high molecular weight species at the time of maximum DNA fragmentation into oligonucleosomes $(24 \mathrm{~h})$, similar to findings reported in T-cell hybridomas undergoing apoptosis [14]. DNA fragmentation into oligonucleosomes was no longer detected after $48 \mathrm{~h}$ incubation with the cytokines, since islet-cell 

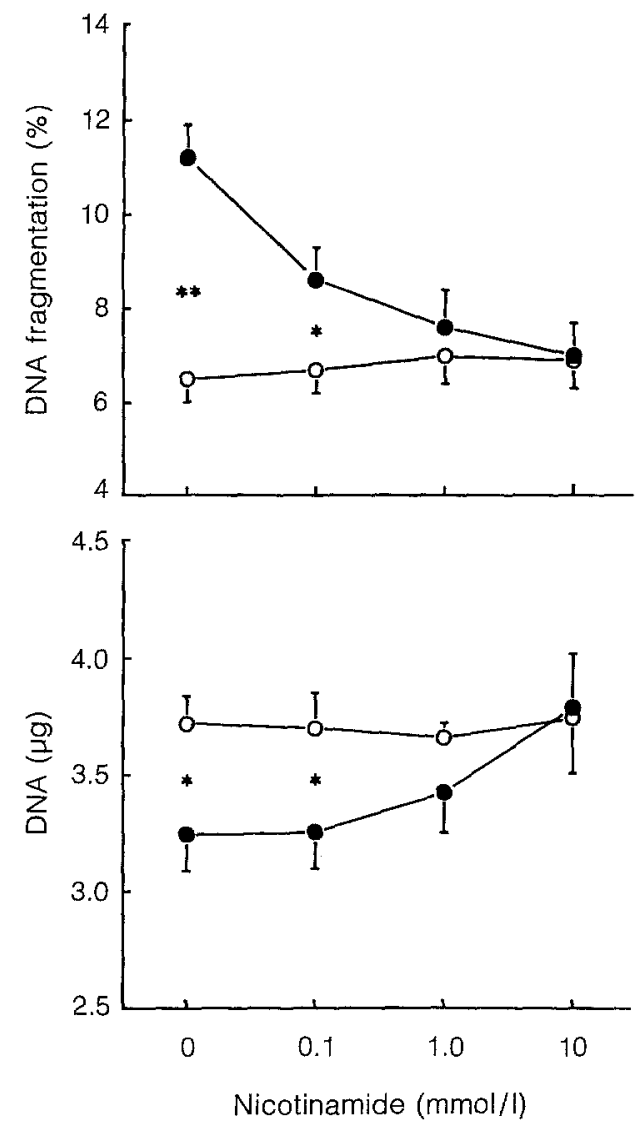

Fig.3. Dose-dependent effects of nicotinamide on cytokine-induced DNA fragmentation and DNA levels in RINm5F cells after $18 \mathrm{~h}$ incubation. Data are means $\pm S E M$ for four experiments. $* p<0.05, * * p<0.02$ compares values for incubations in the absence ( $O$ ) and presence ( $O$ ) of the cytokine combination of interleukin 1 (IL- $1 \beta, 10 \mathrm{U} / \mathrm{ml}$ ), tumour necrosis factor (TNFo, $10^{3} \mathrm{U} / \mathrm{ml}$ ), and interferon gamma (IFN $\gamma, 10^{3} \mathrm{U} / \mathrm{ml}$ )

death was advanced by this time (observed by phase contrast microscopy).

To determine if beta cells participated in the cytokine-induced DNA fragmentation observed in whole islets, two islet beta-cell lines (RINm5F and NIT-1 cells) were studied. DNA fragmentation was monitored by measuring the appearance of ${ }^{125}$ I-labelled DNA in a soluble fraction of DNA, and cell lysis was monitored by measuring release of ${ }^{51} \mathrm{Cr}$-labelled cytosolic proteins from the cells (Fig. 2). Cytokine-induced DNA fragmentation in RINm5F cells was significantly increased at $6 \mathrm{~h}$ whereas cell lysis was not significantly increased until $18 \mathrm{~h}$. Similarly, cytokine-induced DNA fragmentation in NIT-1 cells was significantly increased as early as $3 \mathrm{~h}$, followed by cell lysis at $6 \mathrm{~h}$. In contrast, non-islet cell lines (GH-3, pituitary; $\mathrm{PC}-12$, adrenal) responded differently. GH-3 and PC-12 cells were lysed by the cytokines, however DNA fragmentation was not significant (GH-3 cells) or occurred only after cell lysis (PC-12 cells).

To study further the relationship of cytokine-induced islet-cell killing to DNA fragmentation, nico- tinamide, a known inhibitor of islet-cell killing by various cytotoxins, was added to RINm5F cells incubated with cytokines. Nicotinamide produced a dose-dependent parallel inhibition of cytokine-induced DNA fragmentation and cell (DNA) loss, and $10 \mathrm{mmol} / 1 \mathrm{ni}-$ cotinamide completely prevented both DNA fragmentation and cell destruction by the cytokines (Fig. 3).

\section{Discussion}

This study demonstrates that cytokines can damage DNA in pancreatic islets and islet beta-cell lines. A combination of cytokines (IL- $1 \beta$, TNF $\alpha$ and IFN $\gamma$ ) was required to induce DNA damage and this consisted of DNA fragmentation into oligonucleosomal subunits. This form of subcellular damage is characteristic of apoptotic cell death, in which nuclear damage is the dominant histologic feature [18]. The cytokine combination of IL- $1 \beta$, TNF $\alpha$ and IFN $\gamma$ was cytotoxic to islet beta-cell lines (RINm5F and NIT-1) and non-islet endocrine cell lines (GH-3 and PC-12); however, DNA fragmentation preceded cell lysis only in the islet betacell lines. Nicotinamide prevented both DNA fragmentation and destruction of RINm5F cells by the cytokines. These findings indicate that DNA is an early target of islet beta-cell injury by cytokines and that DNA fragmentation may be a mechanism of cytokine-induced beta-cell killing.

Our findings are similar to those of a recent study reporting that IL- $1 \beta$, in a high concentration $(0.1 \mathrm{nmol} / 1$ $\approx 50 \mathrm{U} / \mathrm{ml}$ ), caused DNA damage in rat islets and a hamster insulinoma cell line [19]. Although IL-1 $\beta$ $(10 \mathrm{U} / \mathrm{ml})$ acting alone, did not cause significant DNA damage in our study, the combination of IL- $1 \beta, \mathrm{TNF} \alpha$ and IFN $\gamma$ did result in significant DNA damage. Our failure to detect DNA damage with $I L-1 \beta$ alone may be related to the assay we used to measure DNA damage. Thus, the DNA assay we used measures amounts of DNA fragmented to small molecular weight species (soluble DNA) and therefore is less sensitive than the method used to detect DNA strand breaks in single cells [19].

Regarding mechanisms of cytokine-induced DNA damage, inhibition of nitric oxide generation by an arginine analogue, $\mathrm{L}-\mathrm{NMMA}$ was reported to prevent IL$1 \beta$-induced DNA damage in rat islet cells and a hamster insulinoma cell line, identifying $\mathrm{NO}$ as a mediator of cytokine-induced DNA damage [19]. We have also found that L-NMMA protects RINm5F insulinoma cells from DNA fragmentation induced by the cytokine combination of IL-1 $\beta$, TNF $\alpha$ and IFN $\gamma[20]$. However, we also found that nicotinamide could prevent the DNA damaging effects of the cytokine combination without inhibiting NO generation [20]. This suggests that NO may be a mediator of cytokine-induced DNA fragmentation $[19,20]$ but that $\mathrm{NO}$-independent mech- 
anisms of cytokine-induced DNA damage in islet cells may also exist and that nicotinamide may act on these pathways [20].

Nicotinamide is a well-documented protector of islet cells from a variety of cytotoxic agents, including alloxan and streptozotocin [21,22], cytotoxic antibodies [21], oxygen free radicals [21, 23], NO [24], and the cytokine combination of TNF $\alpha$ and IFN $\gamma$ [25]. However, mechanisms of nicotinamide-induced protection of islet beta cells from cytotoxic agents are incompletely defined and may depend on the cytotoxic agent. For example, LeDoux et al. [22] reported that nicotinamide decreased alloxan-induced DNA damage, but increased streptozotocin-induced DNA damage in RINm5F cells. This suggested that nicotinamide protected against alloxan by acting as an oxygen free radical scavenger, but protected against streptozotocin by acting as a poly (ADP-ribose) transferase inhibitor. Our finding that cytokine-induced DNA fragmentation was decreased by nicotinamide is similar to that observed using alloxan as a cytotoxic agent in RINm5F cells [22], and suggests that oxygen free radicals are involved in the DNA damaging effects of the cytokines.

Recent reports indicate that nicotinamide can inhibit NO generation by IL-1 $\beta$ in rat islet cells [26] and in RINm5F cells [27]. However, high concentrations of nicotinamide $(10-50 \mathrm{mmol} / \mathrm{l})$ were used in these studies $[26,27]$, and we have recently found that lower concentrations of nicotinamide $(0.1-1 \mathrm{mmol} / \mathrm{l})$ can prevent cytokine-induced DNA fragmentation and death of RIN cells without inhibiting NO generation [20]. Therefore, we believe that nicotinamide acted on some NO-independent mechanism(s) of cytokine-induced cytotoxicity. This may be at a step(s) beyond NO generation since nicotinamide can prevent rat islet-cell lysis by nitroprusside, a chemical NO donor [24].

The present study demonstrates that a combination of cytokines (IL- $1 \beta, \mathrm{TNF} \alpha$ and IFN $\gamma$ ) induces DNA fragmentation and destruction of rat-islet cells and beta-cell lines. Mechanisms involved in cytokine-induced DNA fragmentation and how the latter event is involved in the death of the beta cell remain to be more completely elucidated.

Acknowledgements. This work was supported by grants from the Medical Research Council of Canada and Juvenile Diabetes Foundation International. Alex Rabinovitch is a Medical Scientist of the Alberta Heritage Foundation for Medical Research. We thank Dr. C.D.Helgason for advice on DNA assays and Ms. S.DeMartini for manuscript preparation.

\section{References}

1. Mandrup-Poulsen T, Bendtzen $\mathrm{K}$, Nielsen JH, Bendixen $\mathrm{G}$, Nerup J (1985) Cytokines cause functional and structural damage to isolated islets of Langerhans. Allergy 40: 424429
2. McDaniel ML, Hughes JH, Wolf BA, Easom RA, Turk J (1988) Descriptive and mechanistic considerations of interleukin 1 and insulin secretion. Diabetes 37: 13111315

3. Mandrup-Poulsen T, Helqvist S, Wogensen LD et al. (1990) Cytokines and free radicals as effector molecules in the destruction of pancreatic beta cells. Curr Top Microbiol Immunol 164: 169-193

4. Sandler S, Eizirik DL, Svensson C, Strandell E, Welsh M, Welsh N (1991) Biochemical and molecular actions of interleukin-1 on pancreatic $\beta$-cells. Autoimmunity 10: $241-$ 253

5. Corbett JA, McDaniel ML (1992) Does nitric oxide mediate autoimmune destruction of $\beta$-cells? Possible therapeutic interventions in IDDM. Diabetes 41: 897-903

6. Rabinovitch A (1993) Roles of cytokines in IDDM pathogenesis and islet $\beta$-cell destruction. Diabetes Reviews 1 : 215-240

7. Fehsel K, Jalowy A, Qi S, Burkart V, Hartmann B, Kolb H (1993) Islet cell DNA is a target of inflammatory attack by nitric oxide. Diabetes 42: 496-500

8. Larrick JW, Wright SC (1990) Cytotoxic mechanism of tumor necrosis factor- $\alpha$. FASEB J. 4: 3215-3223

9. Lacy PE, Kostianovski M (1967) Method for the isolation of islets of Langerhans from the rat pancreas. Diabetes 16: 3539

10. Sutton R, Peters M, McShane P, Gray DWR, Morris PJ (1986) Isolation of rat pancreatic islets by ductal injection of collagenase. Transplantation 42: 689-691

11. Duke RC, Sellins KS (1989) Target cell nuclear damage in addition to DNA fragmentation during cytotoxic T lymphocyte-mediated cytolysis. In: Kaplan JG, Green DR, Bleackley RC (eds) Cellular basis of immune modulation, Alan R Liss, New York, pp. 311-314

12. Morgan AR, Lee JS, Pulleybank DE, Murray NL, Evans DH (1979) Ethidium fluorescence assays. Part 1. Physicochemical studies. Nucleic Acids Res 7: 547-569

13. Helgason CD, Shi L, Greenberg AH et al. (1993) DNA fragmentation induced by cytotoxic $T$ lymphocytes can result in target cell death. Exp Cell Res 206: 302-310

14. Shi Y, Szalay MG, Paskar L, Boyer M, Singh B, Green DR (1990) Activation-induced cell death in T-cell hybridomas is due to apoptosis. Morphologic aspects and DNA fragmentation. J Immunol 144: 3326-3333

15. Gazdar AF, Chick WL, Oie HK et al. (1980) Continuous clonal, insulin- and somatostatin-secreting cell lines established from a transplantable rat islet cell tumor. Proc Natl Acad Sci USA 77: 3519-3523

16. Hamaguchi K, Gaskins HR, Leiter EH (1991) NIT-1, a pancreatic $\beta$-cell line established from a transgenic NOD/Lt mouse. Diabetes 40: 842-849

17. Rabinovitch A, Baquerizo H, Pukel C, Sumoski W (1989) Effects of cytokines on rat pancreatic islet cell monolayer cultures: distinction between functional and cytotoxic effects on islet $\beta$-cells. Reg Immunology 2: 77-82

18. Cohen JJ, Duke RC, Fadok VA, Sellins KS (1992) Apoptosis and programmed cell death in immunity. Annu Rev Immunol 10: 267-293

19. Delaney CA, Green MHL, Lowe JE, Green IC (1993) Endogenous nitric oxide induced by interleukin- $1 \beta$ in rat islets of Langerhans and HIT-T15 cells causes significant DNA damage as measured by the 'comet' assay. FEBS Lett 333: 291-295

20. Suarez-Pinzon WL, Strynadka K, Schulz R, Rabinovitch A (1994) Mechanisms of cytokine-induced destruction of rat insulinoma cells: the role of nitric oxide. Endocrinology 134: $1006-1010$ 
21. Pipeleers D, Van de Winkel M (1986) Pancreatic $\beta$ cells possess defense mechanisms against cell-specific toxicity. Proc Natl Acad Sci USA 83: 5267-5271

22. LeDoux SP, Hall CR, Forbes PM, Patton NJ, Wilson GL (1988) Mechanisms of nicotinamide and thymidine protection from alloxan and streptozocin toxicity. Diabetes 37: 1015-1019

23. Burkart V, Koike T, Brenner HH, Kolb H (1992) Oxygen radicals generated by the enzyme xanthine oxidase lyse rat pancreatic islet cells in vitro. Diabetologia 35: 10281034

24. Kallman B, Burkart V, Kroncke KD, Kolb-Bachofen V, Kolb $H$ (1992) Toxicity of chemically generated nitric oxide towards pancreatic islet cells can be prevented by nicotinamide. Life Sci 51: 671-678
25. Yamada K, Ryu E, Nonaka K (1990) Protective effect of nicotinamide and 3 -aminobenzamide in islet cell damage induced by $\gamma$-interferon and tumor necrosis factor. Diabetes Res 13: 85-87

26. Andersen H, Mandrup-Poulsen T, Jørgensen KH, Egeberg J, Nerup J (1993) Nicotinamide inhibits interleukin-1 effects on insulin release and nitric oxide production in rat islets of Langerhans. Autoimmunity 15 (Suppl 1): 59

27. Cetkovic-Cvrlje M, Sandler S, Eizirik DL (1993) Nicotinamide and dexamethasone inhibit interleukin-1-induced intric oxide production by RINm5F cells without decreasing messenger ribonucleic acid expression for nitric oxide synthase. Endocrinology 133: 1739-1743 